IZA DP No. 7261

The Earned Income Tax Credit, Health, and Happiness

Casey Boyd-Swan

Chris M. Herbst

John Ifcher

Homa Zarghamee

March 2013 


\title{
The Earned Income Tax Credit, Health, and Happiness
}

\author{
Casey Boyd-Swan \\ Arizona State University
}

Chris M. Herbst

Arizona State University

and IZA

John Ifcher

Santa Clara University

Homa Zarghamee

Barnard College

\section{Discussion Paper No. 7261 \\ March 2013}

\author{
IZA \\ P.O. Box 7240 \\ 53072 Bonn \\ Germany \\ Phone: +49-228-3894-0 \\ Fax: +49-228-3894-180 \\ E-mail: iza@iza.org
}

\begin{abstract}
Any opinions expressed here are those of the author(s) and not those of IZA. Research published in this series may include views on policy, but the institute itself takes no institutional policy positions. The IZA research network is committed to the IZA Guiding Principles of Research Integrity.

The Institute for the Study of Labor (IZA) in Bonn is a local and virtual international research center and a place of communication between science, politics and business. IZA is an independent nonprofit organization supported by Deutsche Post Foundation. The center is associated with the University of Bonn and offers a stimulating research environment through its international network, workshops and conferences, data service, project support, research visits and doctoral program. IZA engages in (i) original and internationally competitive research in all fields of labor economics, (ii) development of policy concepts, and (iii) dissemination of research results and concepts to the interested public.
\end{abstract}

IZA Discussion Papers often represent preliminary work and are circulated to encourage discussion. Citation of such a paper should account for its provisional character. A revised version may be available directly from the author. 


\section{ABSTRACT}

\section{The Earned Income Tax Credit, Health, and Happiness ${ }^{1}$}

This paper contributes to the small but growing literature evaluating the health effects of the Earned Income Tax Credit (EITC). In particular, we use data from the National Survey of Families and Households to study the impact of the 1990 federal EITC expansion on several outcomes related to mental health and subjective well-being. The identification strategy relies on a difference-in-differences framework to estimate intent-to-treat effects for the post-reform period. Our results suggest that the 1990 EITC reform generated sizeable health benefits for low-skilled mothers. Such women experienced lower depression symptomatology, an increase in self-reported happiness, and improved self-efficacy relative to their childless counterparts. Consistent with previous work, we find that married mothers captured most of the health benefits, with unmarried mothers' health changing very little following the 1990 EITC reform.

JEL Classification: $\quad 11, \mathrm{~J} 00$

Keywords: $\quad$ Earned Income Tax Credit (EITC), happiness, health, subjective well-being

Corresponding author:

Chris M. Herbst

School of Public Affairs

Arizona State University

411 N Central Avenue, Suite 400

Phoenix, AZ 85004-0687

USA

E-mail: chris.herbst@asu.edu

\footnotetext{
${ }^{1}$ All authors contributed equally to this paper. The authors would like to thank participants at the 2013 AEA meetings in San Diego, especially, Carol Graham, for their helpful comments and suggestions.
} 


\section{Introduction}

Over the past three decades, the federal Earned Income Tax Credit (EITC) has become arguably the most important anti-poverty policy in the United States. Enacted in 1975, the EITC was structured initially as a $\$ 400$ refundable tax credit to offset the rise in payroll taxes. Today, the program is viewed primarily as a wage supplement for low-income families, paying maximum credits of $\$ 3,200, \$ 5,200$, and $\$ 5,900$ to working families with one, two, and three (or more) children, respectively (Tax Policy Center, 2012). ${ }^{2}$ Over 26 million families received the EITC in 2010 , totaling $\$ 58.6$ billion in foregone revenue. By comparison, federal expenditures on Temporary Assistance to Needy Families (TANF), the U.S.'s flagship cash-transfer program, were $\$ 15.2$ billion (U.S. Department of Health \& Human Services, 2012). The anti-poverty effects of the EITC are welldocumented. For example, the program in 2010 lifted 6.3 million people, including 3.3 million children, above the poverty line (Center on Budget \& Policy Priorities, 2012).

In response to the growing prominence of the EITC, evaluations of the tax credit have begun to move beyond traditional economic outcomes (e.g., labor supply), focusing increasingly on the EITC's health effects. In particular, recent studies examine whether EITC-induced increases in income have implications for infant health and birth weight (Baker, 2008; Strully et al., 2010; Hoynes et al., 2012), children's cognitive ability test scores (Dahl \& Lochner, 2012), and parents' biomarkers and mental health (Evans \& Garthwaite, 2010). Although the income-health link has been studied heavily across multiple fields (e.g., Ettner, 1996; Case et al., 2002; Seeman et al., 2008), concerns about the endogeneity of income permit only tentative conclusions about its causal effect on health. The EITC papers, on the other hand, are advantageous for assessing the income-health gradient because they generally rely on tax-reform-driven changes in the benefit structure to generate exogenous increases in after-tax income.

\footnotetext{
${ }^{2}$ The credit for families with three or more children was a temporary expansion through 2013 as part of the 2009 American Recovery and Reinvestment Act.
} 
Using data from the National Survey of Families and Households (NSFH), this paper contributes new evidence on the health implications of the EITC. In particular, we examine the impact of the 1990 federal EITC expansion through the Omnibus Budget Reconciliation Act (OBRA90) on adults' self-reported mental health and subjective well-being. Our primary mental health outcome is based on the multi-item Center for Epidemiologic Studies-Depression (CES-D) scale, while the subjective well-being outcomes are drawn from measures of global happiness and self-efficacy. The NSFH provides several advantages for studying the health effects of the EITC. First, the initial wave was administered in 1987 and 1988 - providing pre-OBRA90 health and subjective well-being measures_-while the second wave was administered in 1992, 1993, and 1994 - providing post-reform health and subjective well-being measures. Our identification strategy relies on a differences-in-differences (D-in-D) framework to estimate intent-to-treat (ITT) effects of the EITC. Second, the survey oversampled low-income families, including unmarried women with children, who are key beneficiaries of the EITC. Finally, the survey design and questionnaire allow researchers to construct nuanced measures of family composition. We use these data to more carefully identify potentially eligible EITC recipients (or tax units) than do prior EITC papers. In particular, we ensure that a "qualifying child" meets the relationship and residency requirements including those for students and children with disabilities.

Our empirical analysis begins by replicating the finding in previous studies that tax-reforminduced increases in EITC income have substantial employment effects, especially among unmarried mothers. The D-in-D estimate implies that such women were 8.4 percentage points more likely to be working following the implementation of OBRA90, corresponding to a 17 percent rise in employment. We also find consistent evidence that the EITC has beneficial mental health effects. In particular, low-skilled mothers in the post-OBRA90 period scored lower on the CES-D Depression scale, reported higher levels of happiness, and were more likely to feel efficacious. Interestingly, our results suggest that married mothers - a group whose employment activity did not change after 
OBRA90 - capture most of the EITC's positive health effects. For example, CES-D scores for married mothers improved nearly 15 percent, while those for unmarried mothers improved four percent. These results correspond with a recent paper by Evans and Garthwaite (2010), which finds smaller labor supply effects and larger health effects among married mothers (relative to unmarried mothers) from the OBRA93 EITC expansion. Such results are consistent with a theoretical model in which pure income transfers are capable of generating health benefits.

In addition to informing the literature on the income-health gradient, this paper contributes to at least three other bodies of research. Most directly, it adds to the extensive EITC literature, which to date examines such outcomes as employment (Eissa \& Liebman, 1996; Herbst, 2010; Meyer \& Rosenbaum, 2001); marriage and divorce (Dickert-Conlin \& Houser, 2002; Herbst, 2011), births and abortion (Baughman \& Dickert-Conlin, 2007; Duchovny, 2001; Herbst, 2012a), and material wellbeing (Barrow \& McGranahan, 2000; Neumark \& Wascher, 2001). Second, it complements the small but growing body of research exploring the ways in which self-reported happiness and life satisfaction are influenced by a range of economic and policy phenomena, including gross domestic product (Di Tella et al., 2003), labor market conditions (Wolfers, 2003), gasoline prices (Boyd-Swan \& Herbst, 2012), income taxes (Akay et al., 2012), and cigarette taxes (Gruber and Mullainathan, 2005). This paper particularly complements several recent analyses of the impact of other social safety-net reforms on low-income women's happiness. For example, Ifcher (2011) and Herbst (2012b; 2013) find that the 1996 U.S. welfare reform legislation produced sizeable increases in unmarried mothers' happiness, but that parallel reforms to the child care subsidy system led to reductions in happiness (Herbst \& Tekin, 2012). Finally, by exploiting an exogenous source of variation in income, this paper contributes to the ongoing debate over the casual effect of income on happiness (Luttmer, 2005; Stevenson \& Wolfers, 2008; Easterlin, 2013).

The remainder of the paper proceeds as follows. Section II provides an overview of the EITC, and summarizes the relevant literature on the credit's health effects. Section III introduces the 
NSFH data and describes the creation of the analysis sample. The D-in-D framework is discussed in Section IV, and Section V presents the empirical results. We conclude with a discussion of policy implications in Section VI.

\section{Background}

\section{Overview of the Earned Income Tax Credit}

The EITC was created through the 1975 Tax Reduction Act as a credit for tax filers with children. It was initially intended to achieve three goals: act as a "work bonus" for the working poor, offset some of the growth in payroll taxes, and respond to the 1974 recession by stimulating demand. The credit provided a 10 percent wage subsidy on earnings up to $\$ 4,000$ (for a maximum credit of $\$ 400$ ), which was then phased out at a rate of 10 percent until earnings reached $\$ 8,000$. The EITC was structured as a refundable tax credit, such that if EITC benefits exceeded tax liabilities, families received a check for the difference from the Internal Revenue Service (IRS).

After gaining permanent tax code status in 1978, the EITC experienced its first major reform through the Tax Reform Act of 1986. This law raised the subsidy rate to 14 percent and increased the maximum credit to $\$ 851$. The current paper is concerned primarily with the EITC's second major expansion through the OBRA90. The defining feature of this legislation was the creation of separate benefit schedules for one- and multiple-child families. Eligible families with one child in 1991 received a 16.7 percent wage subsidy (for a maximum credit of $\$ 1,192$ ), while families with two or more children received a 17.3 percent subsidy (for a maximum credit of $\$ 1,235$ ) on earnings up to $\$ 7,140$. The credit then phased out at a rate of about 12 percent until earnings reached $\$ 21,250$. In successive years, the subsidy rate increased to 17.6 percent (18.4 percent) for one-child (multiplechild) families in 1992 and to 18.5 percent (19.5 percent) for one-child (multiple-child) families in 1993.

A third major expansion occurred through the OBRA9. Between 1994 and 1996, the phase-in rate for families with one child increased from 23.6 percent to 34 percent, while the rate for multiple- 
child families grew from 30 percent to 40 percent. By 1996, when the legislation was fully implemented, eligible families with children could receive maximum EITCs of $\$ 2,152$ (for one child) or $\$ 3,556$ (for multiple children). OBRA93 also created a third benefit schedule for childless tax filers, comprising a 7.65 percent subsidy of the first $\$ 4,000$ of earnings and a maximum credit of $\$ 306$.

Eligibility for the EITC is currently determined along several dimensions. First, taxpayers must have non-zero earned income from wages or salary, business self-employment, or farm selfemployment. Second, single and married tax filers are eligible to claim the credit as long as their adjusted gross income is below some threshold. This threshold varies by the year and the number of qualifying children. ${ }^{3}$ The EITC's original design extended eligibility only to families with children, and the credit did not vary with the number of children. However, as previously mentioned, OBRA90 created a large and growing differential benefit schedule for families with two or more children, and OBRA93 created a small EITC for childless tax filers.

Finally, there are three regions in the EITC's benefit structure; thus, it is useful to think of the credit as comprising three separate programs (Browning, 1995). With its negative marginal tax rate, the first region — called the phase-in range — operates likes a wage subsidy by increasing workers' net-of-tax wages. The plateau range, where the credit rate is zero for each additional dollar earned, acts like a lump sum transfer. Finally, the phase-out range essentially adds families' marginal tax rates because of the way it gradually phases out benefits as earnings rise.

\section{Conceptual Framework}

A simple model of the demand for health can be a useful way to illustrate the potential impact of federal EITC expansions on women's health and subjective well-being (Grossman, 1972). Assume that utility is expressed as a function of current health, non-market (leisure) time, the

\footnotetext{
${ }^{3}$ A qualifying child must be a child, grandchild, stepchild, or foster child of the taxpayer; under 19 years old (under 24 if a full-time student) or permanently disabled; and living with the taxpayer for the entire tax year.
} 
consumption of goods and services, and a set of demographic characteristics (e.g., age, the presence and number of children, and educational attainment). In this model, consumption can be healthpromoting (e.g., medical care, services to promote physical activity, and healthy food) or healthdegrading (e.g., sedentary activities and calorie-dense food). The policy context is also important to the production of health, which, for the purposes of this paper, includes reforms to the EITC. An insight from this framework is that EITC expansions are predicted to have ambiguous effects on health and subjective well-being that operate primarily through changes in mothers' non-market time and consumption. We elaborate on these mechanisms below.

Regarding the first mechanism, it is possible that the EITC's wage subsidy increases the opportunity costs associated with leisure, thus creating disincentives for mothers to undertake timeintensive well-being investments. Such women may therefore participate in fewer recreational activities, decrease time spent exercising and preparing healthy meals, and make less use of medical and mental health services. It is also possible that the shift into employment creates a series of demands on mothers' non-market time, especially among those with little or no previous work experience. For example, such women may have to find and pay for reliable child care, arrange transportation to and from work, and grapple with unpredictable or non-standard work schedules. An additional work-related stressor involves the potential loss of health insurance, as low-wage employers do not typically offer such benefits and mothers may lose eligibility for Medicaid. Finally, an indirect work-related consequence of the EITC is that it likely alters the reference group against whom mothers evaluate their well-being. Assuming that health and happiness is greater within the non-welfare working population, it is plausible that the well-being of mothers (who start working because of the EITC) is dampened, at least in the short-run, because of comparisons to healthier and happier people.

Expansions to the EITC can also affect mothers' health and subjective well-being through changes in consumption. In particular, the exogenous increase in income generated by the EITC is 
predicted to alter the mix of goods and services purchased by the mother. These changes may have conflicting effects on health and well-being. On the one hand, rising income may allow mothers to make investments in personal growth, to purchase goods and services that compensate for the reduction in leisure time, and to engage in happiness-enhancing activities (e.g., going to the movies, joining clubs, or dining at restaurants). The additional income may also have positive effects if it is used by mothers to consume technologies that improve mental and physical health (e.g., medical care) and promote healthy lifestyles (e.g., fresh fruits and vegetables). Conversely, it is plausible that mothers respond to EITC-induced increases in income by engaging in unhealthy activities if they are normal goods and services. For example, mothers could use the additional income to purchase cigarettes and alcohol, reduce the home production of meals, and engage in more sedentary activities, all of which may have negative implications for health and subjective well-being. It is also possible that the intra-household allocation of income is made in a way that advantages children, for example, by redistributing resources to children's books and educational materials, extracurricular activities, and medical care. Such a change in resource allocation could therefore leave mothers' own health and subjective well-being unchanged.

\section{Relevant Literature}

To date, only a small set of studies has examined the health effects of the EITC, and most of these studies focus on outcomes related to infants and children. For example, using a D-in-D design, Baker (2008) studies the EITC reform embedded in the OBRA93, finding that the credit increases birth weight by seven to 14 grams and reduces the incidence of low birth weight by 0.4 percent. Two potential mechanisms for the improvement in birth outcomes are more frequent prenatal doctor visits and a reduction in the likelihood of smoking during pregnancy. A more recent study by Hoynes et al. (2012) reexamines the health-at-birth effects of the EITC using a variety of estimation strategies and taking advantage of multiple sources of identifying variation in the EITC. Their results largely confirm those in Baker (2008): a \$1,000 increase in EITC income reduces the incidence of low birth 
weight by seven to 11 percent, and increases the frequency of positive health behaviors during pregnancy. A final study, by Dahl and Lochner (2012), studies the impact of federal EITC reforms between 1993 and 1997 on low-income children's cognitive-ability test scores. Their baseline estimate suggests that a $\$ 1,000$ increase in EITC-driven income raises math and reading test scores in the short-run by six percent of a standard deviation.

To our knowledge, only one prior study examines the impact of the EITC on adult health (Evans \& Garthwaite, 2010). The authors evaluate the EITC reform embedded in the OBRA93, taking advantage of the growing differential benefit for families with two or more children compared to families with one child. Using the Behavioral Risk Factors Surveillance System, their D-in-D estimates indicate that low-skilled mothers with two or more children experienced fewer poor mental days and an increase in self-reported health. The authors then turn to the National Health Examination Nutrition Survey to assess the influence of the EITC on a series of biomarkers. The evidence here suggests that mothers with multiple children experience reductions in various adverse health conditions, including risky levels of diastolic blood pressure, albumin, and C-reactive protein.

The current study adds to this growing literature in a number of ways. First, we examine a different federal EITC reform-OBRA90 - which may help to corroborate whether the positive health effects of the OBRA93 apply to other EITC reforms. Our paper also uses a unique dataset, the National Survey of Families and Households (NSFH), which to our knowledge has not been used by any previous study on the EITC. Coincidentally, the timing of the first two waves of data collection straddles the OBRA90, providing measures of adult health outcomes and demographic characteristics before and after the 1990 EITC reform. Another advantage of the NSFH is that it provides access to numerous health outcomes that have not been considered by previous work. In particular, we examine low-skilled mothers' depression symptomatology through the Center for Epidemiological Studies Depression (CES-D) scale, self-reported happiness, and a variety of indicators of self-esteem. Finally, because the NSFH was originally intended to be used by sociologists and demographers 
interested in studying household structure, the NSFH provides detailed information on intrahousehold relationships, allowing us to more closely simulate the federal EITC definition of a qualifying child.

\section{Data}

Data for this analysis comes from the National Survey of Families and Households (NSFH), a nationally representative sample of individuals ages 16 and older who are living in households and whose primary language is English or Spanish. ${ }^{4}$ The first wave of the NSFH was administered in 1987 and 1988, generating a sample of 13,007 adults through face-to-face and self-administered questionnaires. In the second wave, conducted throughout the period 1992 to 1994, 10,005 individuals from the first wave were interviewed, thus constructing a two-period balanced panel. ${ }^{5}$ Lastly, the NSFH oversampled minority and single-parent families, as well as stepfamilies, recently married couples, and cohabitating couples.

To create the analysis sample, we pool observations for the first two waves and retain individuals likely to be eligible for the EITC or comparable to those who are eligible. Following convention in the EITC literature, we restrict the analysis sample to women aged 16 to 55 who have no more than a high school degree. We then distinguish between unmarried women with and without children and married women with and without children. The group of unmarried women includes never married, separated, divorced, and widowed individuals. Finally, we exploit the richness of the NSFH household questionnaire to carefully simulate the EITC's rules regarding a qualifying child. In particular, the rules stipulate that an eligible child (i) is a biological, adopted, or foster child of the tax filer or the tax filer's spouse/partner; (ii) is aged 0 to 18 (24 if the child is a full-time student) or disabled; and (iii) has resided full-time within the relevant tax unit for at least six months. The NSFH

\footnotetext{
${ }^{4}$ Detailed information on the NSFH can be found in Sweet et al. (1988) and Sweet and Bumpass (1996).

${ }^{5}$ A third wave of the NSFH was initiated in 2001. This wave was excluded from the analysis because it was fielded long after OBRA90 was implemented, and because NSFH administrators substantially changed the criteria for inclusion in the sample.
} 
questionnaire allows us to precisely determine the nature of the relationship between female respondents and children residing in the same household. In addition, we are able to determine the age of each child within a household and whether a given child is a student or disabled. The only eligibility criterion we are unable to simulate is the residency requirement, which has been challenging for most EITC studies.

Our analytic sample allows us to estimate the D-in-D model on three groups of women. We begin with a comparison of all low-skilled women with children (the eventual treatment group) and low-skilled women without children (the eventual comparison group) regardless of marital status. Sample sizes for these analyses range from 3,479 to 5,531 depending on the outcome variable of interest. We then estimate separate D-in-D regressions for unmarried women (with and without children) and married women (with and without children). Sample sizes for the subset of unmarried women range from 1,058 to 2,590, while those for the subset of married women range from 2,420 to 2,802 .

Given that the NSFH has not been used previously in EITC research, we start the D-in-D analysis by attempting to replicate established employment results. To do so, we use reported hoursof-work during the previous week as a measure of mothers' employment status. This is then transformed into a binary indicator that equals unity if the mother reported non-zero hours of paid work in the previous week. ${ }^{6}$ Next, we examine five outcomes related to self-reported mental health and subjective well-being. We begin with a measure of depression symptomology based on an 11item version of the Center for Epidemiological Studies Depression (CES-D) scale (Radloff, 1977). Respondents were asked about the number of days in the previous week they (a) felt bothered by things that usually do not bother them, (b) experienced diminished appetite, (c) felt that they could

\footnotetext{
${ }^{6}$ In addition, we experiment with an alternative measure of employment, which makes use of a question about respondents' absence from work in the previous week. The binary indicator of employment equals unity if a mother reports either non-zero hours of paid employment or zero hours of employment along with indicating that she was absent from work in the previous week. A mothers is coded zero is she reports zero hours of work and was not absent from work. Regression results based on this measure are very similar to those discussed here.
} 
not shake off the blues even with help from family members or friends, (d) felt depressed, (e) felt that everything they did was an effort, (f) felt fearful, (g) slept restlessly, (h) talked less than usual, (i) felt lonely, (j) felt sad, and (k) felt unable to get going. Responses on each item were recoded to conform to the scale's original construction: zero (less than one day), one (one to two days), two (three to four days), and three (five to seven days). Response codes were then summed over the 11 items to produce the CES-D scale with a minimum value of zero and a maximum value of 33 .

Next, we examine a standard questionnaire item tapping explicit feelings about happiness: The happiness question was preceded by the following statement: "Next are some questions about how you see yourself and your life." The interviewer then asked: "First, taking all things together, how would you say things are these days?" Respondents provided an answer on a seven-point scale, where one is defined as "very unhappy" and seven as "very happy." This item measures global subjective well-being or happiness, in that it reflects an averaging of quality-of-life evaluations over multiple domains (Fischer 2009; Kahneman \& Deaton 2010; Kahneman et al. 1997). It is important to note that this item is quite similar to happiness questions found in widely used survey datasets. For example, since 1972 the General Social Survey has asked respondents: "Taken all together, how would you say things are these days-would you say that you are very happy, pretty happy, or not too happy?"

Survey-based measures of happiness are gaining considerable traction in economic and policy analysis. As previously mentioned, happiness as an outcome has already been used in studies of economic growth, labor market conditions, and gasoline prices, in addition to analyses of such government policies as cigarette and income taxes, welfare reforms, and child care subsidies. Implicit in this research is that a reliance on choices (i.e., observed behavior) alone may not fully capture the well-being effects of policy interventions. Data on self-reported happiness is seen as a useful complement to choice-based welfare analysis because it is a direct, effective, and relatively inexpensive measure of well-being. Indeed, several national governments (e.g., Britain, France, 
and-famously_Bhutan) are collecting and using happiness data alongside more traditional measures of economic activity.

In light of the growing prominence of happiness research, happiness measures are undergoing increased scrutiny (e.g., Bertrand \& Mullainathan, 2001; Krueger \& Schkade, 2008). This research shows that reported happiness is highly correlated with an array of physical attributes, including laughing, smiling, and other expressions of positive affect (Frey \& Stutzer, 2002; Layard, 2005). Similarly, happy individuals are rated as such by family and friends, and they reportedly smile and display more positive emotions during social interactions (Helliwell, 2006; Kahneman \& Krueger, 2006). Indicators of physical health, including self-reported overall health status, sleep quality, and clinical measures of depression and anxiety, are also highly correlated with reported happiness (Diener et al. 2006). It is also noteworthy that happiness responds in predictable ways to changing life events - for example, by peaking in the year of a marriage or birth of a child - even though genes account for a significant fraction of one's happiness endowment.

The remaining outcomes are aimed at capturing various dimensions of self-esteem. In particular, we draw on the following statements presented to respondents: "I feel that I'm a person of worth, at least on an equal plane with others," "On the whole, I am satisfied with myself," and "I am able to do things as well as other people." Answers to each statement range from one ("strongly agree") to five ("strongly disagree"). We recode these response-categories into a binary indicator that equals unity if a given respondent indicated any agreement with the statement ("strongly agree" or "agree"), and zero if the respondent either felt neutral toward the statement or expressed any disagreement with it ("neither agree nor disagree," "disagree," or "strongly disagree").

Table 1 provides summary statistics for the sample of unmarried women (with and without children) and married women (with and without children). Consistent with previous work, lowskilled unmarried mothers are less likely to be employed than their childless counterparts (53 percent compared to 68 percent; p<0.01) (e.g., Eissa \& Liebman, 1996). In addition, unmarried mothers 
reveal more depression symptomatology, as evidenced by the higher mean scores on the CES-D scale $(\mathrm{p}<0.01)$, and lower levels of happiness, although the happiness means are not statistically significantly different. Such women also tend to show lower levels of self-esteem than their childless counterparts. For example, about 67 percent of unmarried mothers report some agreement with the statement that "On the whole, I am satisfied with myself," compared to 72 percent among unmarried childless women $(\mathrm{p}<0.11)$. This pattern of lower global happiness and self-efficacy among unmarried mothers is consistent with recent analyses of the DDB Worldwide Communications Life Style Survey (Herbst, 2012) and the General Social Survey (Ifcher \& Zarghamee, 2010). As shown in the last two columns of Table 1, these well-being differences generally apply to, but are less pronounced for, comparisons of low-skilled married women with and without children.

Although the sample is conditioned on age and educational attainment, Table 1 also shows that, regardless of marital status, mothers are more disadvantaged than their childless counterparts. For example, mothers tend to be younger, on average, than non-mothers, less likely to be white, and more likely to be black or Hispanic. Furthermore, unmarried mothers are more likely than their childless counterparts to have less than a high school degree (35 percent compared to 31 percent). Given these differences, we condition the D-in-D regressions on these observable characteristics, as they are potentially correlated with the outcomes of interest.

\section{Identification Strategy}

To examine the impact of the 1990 EITC reform on mothers' mental health and subjective well-being, we rely on a D-in-D estimator. The D-in-D approach involves comparing the change in health and well-being for a treatment group before and after the implementation of OBRA90 to the change experienced by a comparison group. We define the treatment group to include low-skilled (unmarried and married) mothers with children ages 0 to 18. Such women make up the population most likely to be eligible for EITC, and thus influenced by, OBRA90. The comparison group includes low-skilled (unmarried and married) women without children. These individuals are chosen 
to represent the counterfactual changes in health and well-being because they are unlikely to be affected by OBRA90 (given that they do not have a qualifying child and thus are ineligible for the EITC) but participate in similar labor markets, have comparable wages, and have been shown to respond similarly to changes in labor market conditions (as those in the treatment group) (Meyer \& Rosenbaum 2000; 2001).

Expressed formally, the D-in-D estimates can be generated by the following model:

(1) $Y_{\text {ist }}=\beta_{1}$ Treated $_{\text {ist }}+\beta_{2}\left(\right.$ Post $\left.-O B R A 90_{t}\right)+\beta_{3}\left(\right.$ Treated $_{i s t} \times$ Post-OBRA90 $\left._{t}\right)+\mathbf{X}_{\text {ist }}^{\prime} \gamma+\eta_{s}+\varepsilon_{i s t}$,

where $i$ indexes individuals, $s$ indexes state of residence, and $t$ indexes year. The variable $Y$ represents the five outcomes examined in this study: the binary indicator of employment, scores on the continuous CES-D scale, the categorical measures of happiness, and the three binary indicators for self-esteem. The binary outcomes are estimated with a linear probability model (OLS). The CESD scale is estimated using OLS regression; our results are robust to using negative binomial regression methods. The happiness scale is modeled using OLS regression; our results are robust to using an ordered probit model. Once again, our results are robust to the choice of estimator.

The vector given by $\mathbf{X}^{\prime}$ represents a number of observable demographic controls, including age (and age-squared), race (three dummy variables), marital status (four dummy variables), educational attainment (one dummy variable), a dummy variable for the presence of children ages 13 to 18 in the tax unit, and a continuous measure for the number of children ages 0 to 18 in the tax unit. Also included are dummy variables for missing demographic information. The variable Treated is a binary indicator that equals unity if a given individual is an unmarried or married mother, while PostOBRA90 represents binary indicator that equals unity if an observation is drawn from the post-EITC reform period. The EITC changes in OBRA90 took effect in 1991; however, the first year for which we have post-reform data in the NSFH is 1992. Therefore, our post-reform period extends from 1992 to 1994. It is also important to point out that 1994 is the year in which the EITC's OBRA93 changes 
were first implemented. Although only seven percent of our analysis is drawn from 1994, we conduct a series of robustness checks that drop these observations from the analysis. Our results are robust to this alternative definition of Post-OBRA90.

The variable $\eta$ represents a set of state fixed effects as well as interactions between PostOBRA90 and the state fixed effects. These controls mitigate the concern that the 1990 EITC reform might be correlated with state-specific, time-invariant social policies or labor market conditions that are also related to women's mental health and well-being. The parameter of interest is $\beta_{3}$, which yields the D-in-D estimates of the impact of the 1990 EITC reform on low-skilled mothers' mental health and subjective well-being. In particular, the coefficient captures the change in health and well-being among mothers (treatment group) following the implementation of OBRA90, compared to the change experienced by their childless counterparts (comparison group).

The coefficient $\beta_{3}$ is equivalent to the following:

(2) $\beta_{\mathrm{D}-\mathrm{in}-\mathrm{D}}=\left[\mathrm{E}\left(Y_{i} \mid G_{i}=1, T_{i}=1\right)-\left(Y_{i} \mid G_{i}=1, T_{i}=0\right)\right]$

$$
\text { - }\left[\mathrm{E}\left(Y_{i} \mid G_{i}=0, T_{i}=1\right)-\left(Y_{i} \mid G_{i}=0, T_{i}=0\right)\right],
$$

in which the average difference in the comparison group outcome $\left(G_{i}=0\right)$ between the pre-reform $\left(T_{i}\right.$ $=0)$ and post-reform $\left(T_{i}=1\right)$ periods is subtracted from the average difference in the treatment group outcome $\left(G_{i}=1\right)$ over the same period (Herbst, 2013). The second term in (2) is intended to remove biases stemming from common secular trends in mental health and well-being as well as from economic or demographic shocks that similarly influence the outcomes for the treatment and comparison groups. In other words, the comparison group is used to difference out the change in well-being among treatment individuals that would have occurred in the absence of OBRA90. Any differential change in well-being that emerges through the D-in-D parameter $\beta_{3}$ is therefore attributed to the 1990 EITC reform. As with all D-in-D estimators, the key identifying assumption is that the change in well-being over time would have been the same for the treatment and comparison group in 
the absence of OBRA90. In robustness checks, we investigate whether this assumption is likely to hold by exploring pre-reform happiness trends using the General Social Survey (GSS).

It is important to specify that the D-in-D estimate in (1) represents the intent-to-treat (ITT) effect of the OBRA90 EITC reform. We derive the ITT in this study because our treatment group includes women potentially eligible for the EITC, as opposed to those actually receiving the credit. As such, the ITT captures the overall reform-impact by averaging the treatment effect over those in the treatment group who are affected by the treatment (called compliers because they take-up the treatment) and those who are not affected by it (called non-compliers because they do not take-up the treatment). In the context of this analysis, the ITT provides an average effect of the OBRA90 EITC reform across the population of low-skilled (unmarried and married) mothers, some of whom are influenced by the EITC because they receive the credit and others who are not influenced by it. From a policy perspective, the ITT is an important parameter because it details the full impact on mothers' mental health and subjective well-being of expanding the EITC. The ITT effect also has the advantage over other impact estimates, including the treatment on the treated (TOT), in that it circumvents the problem of selection into compliance.

\section{Results}

Tables 2 through 7 provide the main D-in-D results for this paper. The presentation of results is identical across all the tables: Panel A provides the D-in-D estimates for the pooled sample of lowskilled (unmarried and married) women; Panel B shows results for the subset of unmarried women; and Panel C presents results for the subset of married women. Column (1) in each table displays the raw D-in-D estimates, while column (2) conditions on the demographic characteristics and state fixed effects with wave interactions. We present for each model the coefficients and standard errors (in parentheses) of Treated, Post-OBRA90, and Treated $\times$ Post-OBRA90. The standard errors are clustered on the individual. 


\section{Employment}

As previously stated, we begin in Table 2 with a discussion of the employment results as a check on the NSFH's consistency with the vast EITC-labor supply literature. As shown in column (1) of Panel A, the coefficient on Treated suggests that low-skilled (unmarried and married) mothers are less likely to be employed than their childless counterparts. However, as shown by the D-in-D estimate, these mothers witnessed a large relative increase in employment following the implementation of the OBRA90 EITC reform. The raw D-in-D estimate implies a statistically significant increase in the likelihood of employment of 9.2 percentage points, an estimate that becomes only somewhat smaller (7.9 percentage points) and remains statistically significant when the full set of controls is added in column (2). Given the pre-reform employment mean of 0.52 , the full model D-in-D estimate corresponds to a 15 percent increase in mothers' employment following the implementation of OBRA90.

Looking at Panels B and C, it is clear that the positive employment effect of OBRA90 is concentrated within the subset of unmarried mothers. Column (2) of Panel B shows that unmarried mothers witnessed a precisely estimated 8.4 percentage point increase in the likelihood of working, corresponding to a 17 percent relative rise in employment. On the other hand, employment among married mothers increased by an imprecisely estimated 4.8 percentage points [column (2) of Panel C], representing a 9 percent effect from the pre-treatment mean. The differential employment results for unmarried and married mothers are consistent with previous research. For example, using the Current Population Survey (CPS) to study the 1993 EITC reform, Evans and Garthwaite (2010) estimate a 12 percent employment increase for unmarried mothers, but only a two percent increase for married mothers. A similar set of results are provided by Eissa and Hoynes (2004), who study the family labor supply response to 1986, 1990, and 1993 EITC expansions. The authors find that while such reforms produced small employment increases among married men, these increases were more than offset by employment reductions among married women. 


\section{Depression Symptomatology}

We now consider the primary outcomes for this study, in particular, those pertaining to mothers' mental health and subjective well-being. We begin with the CES-D scale, which captures depression symptomatology. These results are presented in Table 3. Recall that higher scores on the CES-D scale are indicative of an increase in depression symptomatology. As shown in column (2) of Panel A, it appears that the OBRA90 EITC reform had a beneficial effect on low-skilled mothers' depression, generating about a one-point reduction in the CES-D scale. There are several ways to interpret the magnitude of this effect. First, as we did with the employment outcome, we can compare the D-in-D estimate to the pre-reform mean for the treatment group (10.3). Doing so suggests that low-skilled mothers witnessed a 10 percent reduction in depression symptomatology after the implementation of OBRA90. Another approach is to calculate an effect size by rescaling the CES-D to have a mean of zero and a standard deviation of $10 .^{7}$ Our estimate implies that the 1990 EITC reform produced a 0.14 standard deviation decrease in mothers' scores on the depression scale.

Turning to the separate analyses of unmarried (Panel B) and married (Panel C) women, we find that these positive mental health effects are pronounced within the subset of married mothers. Specifically, low-skilled married mothers witnessed a 1.3-point decrease in CES-D scores following the implementation of OBRA90 [column (2) of Panel B]. This corresponds to a 15 percent, or nearly 0.20 standard deviation, reduction in depression symptomatology. Unmarried mothers, on the other hand, experienced an imprecisely estimated 0.5-point decrease in the CES-D [column (2) of Panel $\mathrm{B}]$, which is about a four percent reduction from the pre-reform mean or an effect size of 0.08 standard deviations. The pattern of our CES-D results is consistent with the mental health effects presented in Evans and Garthwaite (2010). Specifically, they find that the positive mental health effects of the 1993 EITC reform (e.g., declines in the number of bad mental health days in the

\footnotetext{
${ }^{7}$ Effect sizes are then calculated by reestimating the model and dividing the D-in-D coefficient by 10 .
} 
previous month) are limited to low-skilled married mothers, with unmarried mothers experiencing very little change in their health status. As will be shown shortly, this pattern applies to the remaining well-being outcomes examined in the NSFH.

Appendix Table 1 presents separate D-in-D estimates for the eleven items that compose the CES-D scale. We code each item as a binary indicator that equals unity if a given respondent experienced the symptom in the previous week and zero if not. To conserve space, we present only the D-in-D estimates. Column (1) presents the full sample D-in-D results, while columns (2) and (3) present the results for unmarried and married women, respectively. Looking at the full sample results, we find that low-skilled mothers show marked improvement in most of the individual CES-D items, with the D-in-D coefficient on eight of 11 items statistically significant. Although the CES-D scores for unmarried mothers did not improve after OBRA90, all of the individual items point to improvements, and estimates on four of 11 individual items are statistically significant. Perhaps the most noteworthy finding is the 10.7 percentage point increase in the probability of not feeling depressed in the last week. Married mothers showed statistically significant improvements in six of 11 items, with the D-in-D estimates for "depressed," "lonely," and "talks less" being particularly strong.

\section{Global Happiness}

We now consider the impact of OBRA90's EITC reform on mothers' self-reported happiness. The D-in-D happiness results are presented in Table 4. Looking first at the sample of all low-skilled women (Panel A), we find that once the full set of controls are included, mothers and non-mothers have similar levels of reported happiness. In addition, the D-in-D estimate reveals that, together, the happiness of unmarried and married mothers did not change substantially following the implementation of OBRA90. In particular, the full model estimate [column (2)] implies an increase of approximately 0.1 points on the happiness scale, an effect that is imprecisely estimated. 
This estimate, however, masks important treatment effect heterogeneity across unmarried and married mothers. The D-in-D estimate in Panel B implies that happiness among unmarried mothers was virtually unchanged after the 1990 EITC reform. Married mothers, on the other hand, witnessed a precisely estimated 0.2 -point increase in the happiness scale, corresponding to a four percent rise in self-reported happiness. In results not reported in Table 4, we explored the distributional effects of the OBRA90 EITC reform. In particular, we created separate binary indicators that equal unity if a respondent is in the bottom two or top two happiness categories. We then re-estimated the D-in-D regressions for unmarried and married women. In neither case was the D-in-D estimate economically important or precisely estimated for unmarried mothers. The results for married mothers suggest that such women became 1.6 percentage points less likely to be in the bottom happiness categories and 8.0 percentage points more likely to be in the top happiness categories following the implementation of OBRA90. Given that 3.0 percent of pre-reform married mothers are in the bottom categories and 54.8 percent are in the top categories, these marginal effects translate to well-being improvements of 53 percent and 15 percent, respectively.

\section{Self-Efficacy}

Tables 5 through 7 present the D-in-D results for the three measures of self-efficacy. Recall that the statements are as follows: "I feel that I'm a person of worth, at least on an equal plan with others;" "On the whole, I am satisfied with myself;" and "I am able to do things as well as other people." We recode the original response categories into a binary indicator of agreement with the statement.

Generally speaking, the pattern of results emerging from Tables 5 through 7 is consistent with that for the CES-D and happiness outcomes. On the one hand, there appear to be no changes in unmarried mothers' self-efficacy following the implementation of OBRA90. In no case is the D-in-D estimate statistically significant. It should be noted, though, that the D-in-D estimates are consistently negatively signed, suggesting that unmarried mothers witnessed a reduction in self- 
efficacy. In at least one case the D-in-D estimate is potentially substantively meaningful: unmarried mothers became 9.0 percentage points less likely to indicate any agreement with the statement "I am able to do things as well as other people." Given that 83.3 percent of pre-reform unmarried mothers reported some agreement with the statement, the marginal effect corresponds to well-being reduction of nearly 11 percent.

On the other hand, the measures of self-efficacy among married mothers show fairly consistent improvement after OBRA90 was implemented. Married mothers became 6.5 percentage points more likely to agree that they are a person of worth (Table 5), 4.7 percentage points more likely to be self-satisfied (Table 6), and 7.3 percentage points more likely to feel able to do things as well as others (Table 7). In addition, the first and third of these D-in-D estimates are precisely estimated, and they imply well-being increases of seven percent and nine percent, respectively.

\section{Robustness Checks}

In this section, we discuss results from a battery of specification tests intended to check the robustness of the main D-in-D results. Our main robustness checks are presented in Table 8. Panel A displays the D-in-D estimates for unmarried women, and Panel B presents the analogous results for married women. Each column presents results from a different specification check.

We begin in column (1) by including a set of month-of-interview indicators. Interviews for the NSFH were conducted on a rolling basis through the year, raising the concern that seasonal patterns in mental health and subjective well-being are potentially influencing the results. Our D-inD estimates are robust to the inclusion of these monthly indicator variables. In particular, the employment estimate for unmarried mothers is of a similar magnitude and remains precisely estimated. The health results for married mothers also remain intact.

Recall that the NSFH conducted about seven percent of its wave-two interviews in 1994, the year in which the 1993 EITC expansion was initially implemented. To test whether our results are driven by the commingling of post-reform periods for two EITC expansions (OBRA90 and 
OBRA93), we re-estimate the D-in-D models dropping the 1994 observations from the analysis. Results from this exercise are presented in column (2). Fortunately, nearly all of our estimates are robust to this sample exclusion. The most noticeable change occurs to the D-in-D employment estimate for unmarried mothers. The magnitude of the coefficient decreases somewhat and becomes imprecisely estimated. However, the D-in-D health effects for married mothers are very similar to main results, suggesting that they are not driven by the EITC reform embedded in OBRA93.

One of the key identifying assumptions underlying the D-in-D estimates is that no other economic or policy shocks coincided with the implementation of OBRA90. If such a shock occurred, we risk attributing the estimated D-in-D effects to this event rather than the OBRA90 EITC reform. Although the full model includes state fixed effects (with wave interactions), we take two additional steps to control for unobserved shocks. First, we control more flexibly for time effects by replacing Post with separate year indicator variables and interacting each with the state fixed effects. Results from this specification are shown in column (3). We then include in the model state-specific linear time trends, which allow any state-level unobservables that are correlated with OBRA90 and the outcomes to trend differently across states. Results from this specification are shown in column (4). The main D-in-D estimates for both unmarried and married mothers are robust to the inclusion of these controls.

The final robustness check, presented in column (5), provides a falsification test. Recall that the analysis sample is constructed to include women who are likely to be eligible for the EITC. Thus, we have limited the sample to low-skilled prime working-age women, defined as those with no more than a high school degree and those ages 16 to 55. If the D-in-D estimates from this sample definition are in fact due to the OBRA90 EITC reform, analyses based on a broadened set of sample definitions should generate estimates that are smaller than those presented in Tables 2 through 7 . The analyses in column (5) remove both the age and education restrictions, thereby expanding the analysis sample to include women comparatively unlikely to be eligible for the EITC. Doing so reduces the magnitude 
of unmarried mothers' employment response to an imprecisely estimated 1.7 percentage (from 8.4 percentage points), and decreases the employment effect for married mothers by about half. Looking at the health outcomes for married mothers, we find that the D-in-D estimates for the CES-D scale, happiness scale, and self-worth measures decrease substantially and become imprecisely estimated. Although the new sample definition leads to reductions in the measures of self-satisfaction and selfefficacy, the D-in-D estimate for the former becomes marginally statistically significant and the latter remains significant. This can be explained by the fact that the broadened sample definition yields larger sample sizes, and thus smaller standard errors. Taken together, the falsification tests provide fairly strong evidence in support of our main D-in-D results.

Finally, we discuss one more set of robustness checks. As previously mentioned, the validity of the D-in-D estimates rests on the assumption of common trends in the outcome measures for the treatment and comparison groups in the absence of OBRA90. If treated and untreated women follow different time paths in mental health or subjective well-being, the estimated effects of the 1990 EITC reform could reflect these differences. Given the importance of this assumption, we assess the degree of similarity in pre-reform happiness trends across unmarried and married women with and without children. Although it is not possible to examine post-OBRA90 trends in the absence of reform, a finding of common pre-reform trends may bolster confidence in the ability to extrapolate these into the post-reform period. Table 9 presents results from an ordered probit happiness regression on separate linear time trends for unmarried women with and without children (first row) and married women with and without children (second row), including a full set of demographic controls. Given that the NSFH does not provide pre-OBRA90 data, we rely on pooled cross-sections of the General Social Survey (GSS) between 1972 and 1990 to conduct the analyses. The GSS has consistently 
asked respondents a happiness question comparable to that in the NSFH. ${ }^{8}$ Columns (2) and (3) present the time trend coefficients, and column (3) tests the null hypothesis of no difference in the trends across the treatment and comparison groups. We find consistent evidence that the preOBRA90 happiness trends are not significantly different across mothers and their childless counterparts. Such similarities increase our confidence that the D-in-D EITC estimates are in fact due to the policy shock represented by OBRA90.

\section{Conclusion}

Since its enactment in 1975, the EITC has grown into arguably the most important antipoverty program in the U.S. Indeed, a unique quality of the program is that it aggressively redistributes income to disadvantaged families while generating strong labor supply incentives. The EITC does this because its benefits are conditioned on participation in the paid labor force. A large body of work confirms empirically that EITC expansions are associated with non-trivial increases in employment among low-skilled unmarried mothers. In fact, some previous research attributes up to one-third of single mothers' employment growth throughout the 1990s to the EITC's multiple expansions (Looney, 2005; Grogger, 2003). On the other hand, the program appears to have either no effect or a small negative effect on married mothers' employment.

More recently, scholars have begun to focus on whether EITC-induced increases in income have discernible health effects. Motivated by previous research that income can buffer against negative health shocks, a small but growing set of papers examines the impact of tax-reform-induced increases in EITC income on infant (Hoynes et al., 2012), child (Dahl \& Lochner, 2012), and adult (Evans \& Garthwaite, 2012) health and development outcomes. An advantage of these papers over those that study directly the income-health gradient is that they rely on policy shocks to generate exogenous increases in income. Results from this body of work are fairly consistent: EITC-induced

\footnotetext{
${ }^{8}$ Unfortunately, self-reported happiness is the only outcome common to both surveys, and thus the only outcome for which we can investigate pre-reform trends in the outcomes under investigation.
} 
increases in income yield positive health effects in the form of improved birth outcomes, gains in children's cognitive ability test scores, and increased mental health and health related behaviors among adults.

This paper contributes new evidence on the EITC-health link by using the NSFH to study the impact of the OBRA90 EITC expansion on low-skilled mothers' mental health, happiness, and selfefficacy. We begin by confirming previous EITC research that the 1990 tax reform generated sizeable positive effects on unmarried mothers' employment, but no discernible effects for married mothers. We then find consistent evidence that the EITC led to improvements in mental health and subjective well-being, especially among married mothers. Following the implementation of OBRA90, married mothers showed less depression symptomatology, as evidenced by lower scores on the CES-D, higher levels of happiness, and a greater sense of self-efficacy. Unmarried mothers, on the other hand, experienced very little change in mental health and subjective well-being after OBRA90.

The finding that the EITC's beneficial health effects are evident only among married mothers - a group whose employment was not influenced by the reform-is consistent with the results in Evans and Garthwaite's (2010) analysis of the OBRA93. To understand why this is the case, it is useful to identify the mechanisms through which the EITC may affect health and wellbeing. As previously stated, the income generated by the EITC - through both additional earnings and the negative income tax - is a potentially important channel. Indeed, there is a large literature outside of the EITC showing robust associations between income and improved physical health outcomes, including lower suicide propensities (Ruhm, 2000), increased self-reported health (House et al., 1990), and fewer acute medical conditions (Ruhm, 2003). A parallel happiness literature finds consistent positive correlations between income and happiness (e.g., Stevenson \& Wolfers, 2008). Another channel stems from the employment effects of the EITC. Indeed, several studies find that psychological health is lower among the unemployed, controlling for income, with longer periods of 
unemployment leading to steeper declines in well-being (Blanchflower \& Oswald, 2004; Clark \& Oswald, 1994; Di Tella et al., 2001; Helliwell, 2003). Furthermore, the unemployed are more likely to experience depression and commit suicide (Viinamaeki et al., 1996). That these results hold after conditioning on income suggests a strong role for psychic or stigma costs associated with unemployment (Murphy \& Athanasou, 1999).

This discussion suggests that future research on the EITC-health link could focus on several areas. First, it is important to understand the ways in which EITC payments influence health-related behaviors, including cigarettes and alcohol purchases, eating and physical activity patterns, and the consumption of health-promoting versus health-degrading goods and services. Another stream of research might focus on the time-use effects of the EITC. For example, one question to explore is whether low-skilled mothers allocate more leisure time to well-being-enhancing activities, perhaps because EITC-generated income is used to purchase durable goods like clothes and dish washers, thus increasing time available for other activities. Finally, it might be useful to examine whether, and how, mothers' social networks are altered by the EITC. It is reasonable to assume that mental health and happiness are influenced by one's access to multiple forms of family, friend, and social networks. The employment and income effects of the EITC imply that mothers' out-of-work networks may become less prominent, while those developing inside the workplace are likely to play a more central role. If participation in these varying social contexts is associated with different types of stressors or emotional supports, then changes in social networks could be one of the (indirect) mechanisms through which the EITC is influencing mental health and happiness. 


\section{References}

Akay, A., Bargain, O., Dolls, M., Neumann, D., Peichl, A., \& Siegloch, S. (2012). Happy taxpayers? Income taxation and well-being. IZA Discussion Paper No. 6999. Bonn, Germany: Institute for the Study of Labor.

Baker, K. (2008). Do Cash Transfer Programs Improve Infant Health: Evidence from the 1993 Expansion of the Earned Income Tax Credit. Working Paper. University of Notre Dame.

Barrow, L. \& McGranahan, L. (2000). The Effects of the Earned Income Credit on the Seasonality of Household Expenditures. National Tax Journal, 53, 1211-1243.

Baughman, R. \& Dickert-Conlin, S. (2009). The Earned Income Tax Credit and Fertility. Journal of Population Economics, 22, 537-563.

Blanchflower, D. \& Oswald, A. (2004). Well-being over time in Britain and the USA. Journal of Public Economics, 88, 1359-1386.

Boyd-Swan, C. \& Herbst, C.M. (2012). Pain at the pump: gasoline prices and subjective well-being. Journal of Urban Economics, 72, 160-175.

Case, A., Lubotsky, D. \& Paxson, C. (2002). Economic Status and Health in Childhood: The Origins of the Gradient. American Economic Review, 92,1308-1334.

Clark, A. \& Oswald, A. (1994). Unhappiness and unemployment. Economic Journal, 104, 648659.

Center on Budget and Policy Priorities. (2012). Policy Basics: The Earned Income Tax Credit. Available at: http://www.cbpp.org/cms/index.cfm?fa=view\&id=2505. Washington, DC: Center on Budget and Policy Priorities.

Dahl, G. \& Lochner, L. (2012). The Impact of Family Income on Child Achievement: Evidence from the Earned Income Tax Credit. American Economic Review, 102, 1927-1956.

Di Tella, R., MacCulloch, R., \& Oswald, A. (2001). Preferences over inflation and unemployment: Evidence from surveys of happiness. American Economic Review, 91, 335-341.

Di Tella, R., MacCulloch, R., Oswald, A. (2003). The macroeconomics of happiness. Review of Economics and Statistics, 85, 809-827.

Dickert-Conlin, S. \& Houser, S. (2002). The Earned Income Tax Credit and Marriage. National Tax Journal, 55, 25-40.

Duchovny, N., 2001. The earned income tax credit and fertility. Unpublished Doctoral Dissertation. College Park, MD: Department of Economics, University of Maryland, College Park.

Easterlin, R. (2013). Happiness and economic growth: The evidence. Discussion Paper No. 7187. Bonn, Gernmany: Institute for the Study of Labor (IZA). 
Eissa, N. \& Leibman, J. (1996). Labor Supply Response to the Earned Income Tax Credit. Quarterly Journal of Economics, 111, 605-637.

Ettner, S. (1996). New evidence on the relationship between income and health. Journal of Health Economics, 15, 67-85.

Evans, W. \& Garthwaite, C. (2010). Giving mom a break: The impact of higher EITC payments on maternal health. NBER Working Paper No. 16296. Cambridge, MA: National Bureau of Economic Research.

Fischer, J. (2009). Subjective well-being as welfare measure: concepts and methodology. Munich Personal RePEc Archive Working Paper No 16619.

Grogger, J. (2003). The effects of time limits, the EITC, and other policy changes on welfare use, work, and income among female-headed families. Review of Economics and Statistics, 85, 394-408.

Gruber, J., Mullainathan, S., 2005. Do cigarette taxes make smokers happier? Advances in Economic Analysis and Policy, 5 (Article 4).

Helliwell, J. (2003). How's life? Combining individual and national variables to explain subjective well-being. Economic Modelling, 20, 331-360.

Herbst, C.M. (2010). The labor supply effects of child care costs and wages in the presence of subsidies and the Earned Income Tax Credit. Review of Economics of the Household, 8, 199-230.

Herbst, C.M. (2011). The impact of the Earned Income Tax Credit on marriage and divorce: evidence from flow data. Population Research and Policy Review, 30, 101-128.

Herbst, C.M. (2012a). The Earned Income Tax Credit and abortion. Social Science Research, 40, 1638-1651.

Herbst, C.M. (2012b). Footloose and Fancy Free? Two Decades of Single Mothers' Subjective WellBeing. Social Service Review, 86, 189-222.

Herbst, C.M. (2013). Welfare reform and the subjective well-being of single mothers. Journal of Population Economics, 26, 203-238.

Herbst, C.M. \& Tekin, E. (2012). Child care subsidies, maternal well-being, and child-parent interactions: Evidence from three nationally representative datasets. NBER Working Paper No. 17774. Cambridge, MA: National Bureau of Economic Research.

Hoynes, H., Miller, D., \& Simon, D. (2012). Income, the Earned Income Tax Credit, and infant health. Working Paper. Department of Economics, University of California, Davis.

Ifcher J. (2011). The happiness of single mothers after welfare reform. BE Journal of Economic Analysis and Policy, 11, 1-27.

Ifcher J, Zarghamee H. (2010). Trends in the happiness of single mothers: Evidence from the General Social Survey. Working Paper Department of Economics Santa Clara University. 
Kahneman D., \& Deaton, A. (2010). High income improves evaluation of life but not emotional wellbeing. Proceedings of the National Academy of Sciences USA, 107, 16489-16493

Kahneman D., Wakker P., \& Sarin, R. (1997). Back to Bentham? Explorations of experienced utility. Quarterly Journal of Economics, 112, 375-405.

Looney, A. (2005). The effects of welfare reform and related policies on single mothers' welfare use and employment in the 1990s. Finance and Economics Discussion Series, Division of Research, Statistics, and Monetary Affairs. Federal Reserve Board: Washington, DC.

Meyer, B. \& Rosenbaum, D. (2001). Welfare, the Earned Income Tax Credit, and the Labor Supply of Single Mothers. Quarterly Journal of Economics, 116, 1063-1114.

Neumark, D. \& Wascher, W. (2001). Using the EITC to help Poor Families: New Evidence and a Comparison with the Minimum Wage. National Tax Journal, 54, 281-317.

Radloff, L. (1977). The CES-D scale: A self-report depression scale for research in the general population. Applied Psychological Measurement, 1, 385-401.

Ruhm, C. (2000). Are recessions good for your health? Quarterly Journal of Economics, 115, 617650.

Ruhm, C. (2003). Good times make you sick. Journal of Health Economics, 22, 637-658.

Seeman, Teresa E., Sharon S. Merkin, Eileen Crimmins, Brandon Koretz, Susan Charette, \& Arun Karlamangla. (2008). Education, Income and Ethnic Differences in Cumulative Biological 46 Risk Profiles in a National Sample of U.S. Adults: NHANES III (1988-1994). Social Science and Medicine 66(1): 72-87.

Stevenson, B. \& Wolfers, J. (2008). Economic growth and subjective well-being. Reassessing the Easterlin paradox. Brookings Papers on Economic Activity, 1, 1-102.

Strully, K., Rehkopf, D. \& Xuan, Z. (2010). Effects of Prenatal Poverty on Infant Health: State Earned Income Tax Credits and Birth Weight. American Sociological Review, 534.

Sweet, J. \& Bumpass, L. (1996). The National Survey of Families and Households - Waves 1 and 2: Data Description and Documentation. Center for Demography and Ecology, University of Wisconsin-Madison (http://www.ssc.wisc.edu/nsfh/home.htm).

Sweet, J., Bumpass, L. \& Call, V. (1988). The Design and Content of The National Survey of Families and Households. Center for Demography and Ecology, University of Wisconsin-Madison, NSFH Working Paper No. 1.

Tax Policy Center. (2012). Historical EITC Parameters. Available at: http://www.taxpolicycenter.org/taxfacts/displayafact.cfm?Docid=36. Washington, DC: BrookingsUrban Tax Policy Center. 
U.S. Department of Health and Human Services. (2012). TANF Financial Data: FY 2011. Available at: http://www.acf.hhs.gov/programs/ofa/resource/tanf-financial-data-fy-2011. Washington, DC: U.S. Department of Health and Human Services.

Viinamaeki, H., Koskela, K., Niskanen, L. (1996). Rapidly declining mental well-being during unemployment. European Journal of Psychiatry, 10, 215-221.

Wolfers, J. (2003). Is business cycle volatility costly? Evidence from surveys of subjective wellbeing. International Finance, 6, 1-26. 
Table 1: Summary Statistics for the NSFH Sample

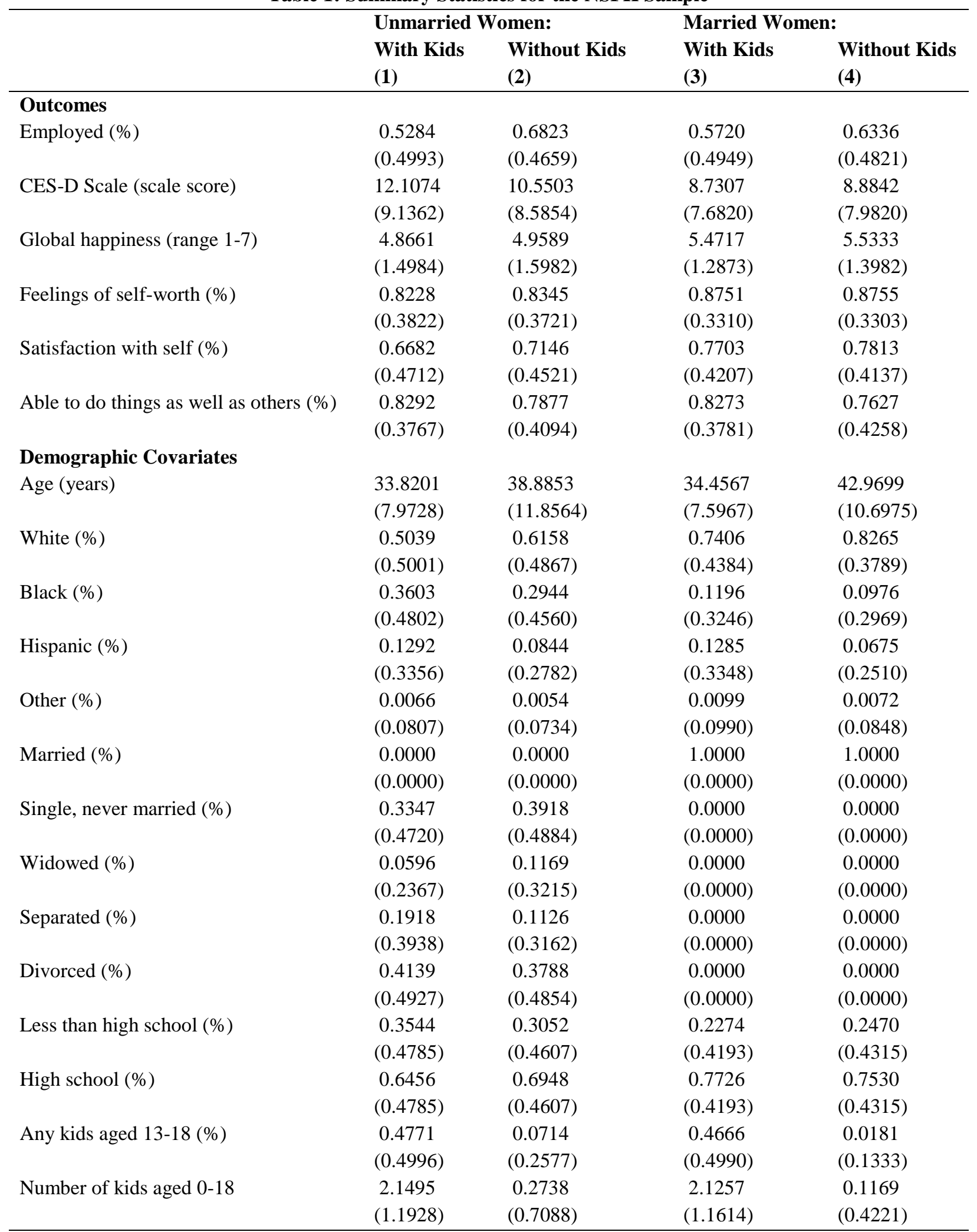

Notes: Calculations are based on the National Survey for Families and Households for wave 1 (1987-1988) and wave 2 (1992-1994).

Standard deviations are reported in parentheses 
Table 2: The Impact of the EITC on Employment

\begin{tabular}{lll}
\hline Variable & $\mathbf{( 1 )}$ & $\mathbf{( 2 )}$ \\
\hline $\begin{array}{l}\text { Panel A: All Women } \\
\text { Treated }\end{array}$ & $-0.1423 * * *$ & $-0.0957 * * *$ \\
Post-Reform & $(0.0181)$ & $(0.0221)$ \\
& -0.0055 & -0.0656 \\
Treated*Post-Reform & $(0.0208)$ & $(0.0458)$ \\
& $0.0919 * * *$ & $0.0791 * * *$ \\
& $(0.0261)$ & $(0.0261)$ \\
Demographic Controls & & Yes \\
State Fixed Effects with Wave Interactions & No & Yes \\
Observations & No & 5,524 \\
Pre-Treatment Mean for Treated Group & 5,529 &
\end{tabular}

\section{Panel B: Unmarried Women}

Treated

Post-Reform

Treated*Post-Reform

$\begin{array}{ll}-0.1866 * * * & -0.1217 * * * \\ (0.0249) & (0.0308) \\ -0.0173 & -0.0978 \\ (0.0297) & (0.0686) \\ 0.0925 * * & 0.0844 * * \\ (0.0385) & (0.0385)\end{array}$

No Yes

No Yes

$2,590 \quad 2,587$

0.5027

Pre-Treatment Mean for Treated Group

\begin{tabular}{|c|c|c|}
\hline \multicolumn{3}{|l|}{ Panel C: Married Women } \\
\hline \multirow[t]{2}{*}{ Treated } & $-0.0960 * * *$ & $-0.0624 *$ \\
\hline & $(0.0262)$ & $(0.0327)$ \\
\hline \multirow[t]{2}{*}{ Post-Reform } & 0.0083 & -0.0329 \\
\hline & $(0.0304)$ & $(0.0662)$ \\
\hline \multirow[t]{2}{*}{ Treated*Post-Reform } & $0.0807 * *$ & 0.0484 \\
\hline & $(0.0370)$ & $(0.0374)$ \\
\hline Demographic Controls & No & Yes \\
\hline State Fixed Effects with Wave Interactions & No & Yes \\
\hline Observations & 2,939 & 2,937 \\
\hline Pre-Treatment Mean for Treated Group & 0.5342 & \\
\hline \multicolumn{3}{|c|}{$\begin{array}{l}\text { Notes: Analyses are based on the National Survey of Families and Households for wave } 1 \text { (1987-1988) } \\
\text { and wave } 2 \text { (1992-1994). Standard errors, reported in parentheses, are adjusted for individual-level } \\
\text { clustering. The dependent variable is a binary indicator that equals unity if a given respondent was } \\
\text { employed in the previous week. Demographic controls include age, age-squared, race, marital status, } \\
\text { educational attainment, presence of children aged } 13-18 \text { in the household, and number of children } \\
\text { between the ages of } 0-18 \text { in the household. Missing dummy variables were created in cases where } \\
\text { demographic information was missing. ***, **, * indicate statistical significance at the } 0.01,0.05 \text {, and } \\
0.10 \text { levels, respectively. }\end{array}$} \\
\hline
\end{tabular}


Table 3: The Impact of the EITC on Depression Symptomatology (CES-D Scale)

\begin{tabular}{lll}
\hline Variable & $(\mathbf{1})$ & $\mathbf{( 2 )}$ \\
\hline Panel A: All Women & & \\
$\quad$ Treated & $0.9279^{* * *}$ & -0.2408 \\
& $(0.3214)$ & $(0.4128)$ \\
\multicolumn{1}{c}{ Post-Reform } & $0.9762^{* *}$ & $1.9410^{* *}$ \\
& $(0.3824)$ & $(0.8736)$ \\
\multicolumn{1}{c}{ Treated*Post-Reform } & $-1.1940^{* *}$ & $-0.9878^{* *}$ \\
& $(0.4783)$ & $(0.4875)$ \\
& & \\
Demographic Controls & No & Yes \\
State Fixed Effects with Wave Interactions & No & Yes \\
Observations & 5,231 & 5,226 \\
Pre-Treatment Mean for Treated Group & 10.2901 & \\
\end{tabular}

\begin{tabular}{|c|c|c|}
\hline \multicolumn{3}{|l|}{ Panel B: Unmarried Women } \\
\hline Treated & $\begin{array}{l}1.7767 * * * \\
(0.4732)\end{array}$ & $\begin{array}{c}0.6214 \\
(0.6195)\end{array}$ \\
\hline Post-Reform & $\begin{array}{c}0.7620 \\
(0.5528)\end{array}$ & $\begin{array}{l}3.0616^{* *} \\
(1.3547)\end{array}$ \\
\hline Treated*Post-Reform & $\begin{array}{l}-0.5077 \\
(0.7320)\end{array}$ & $\begin{array}{l}-0.5340 \\
(0.7679)\end{array}$ \\
\hline Demographic Controls & No & Yes \\
\hline State Fixed Effects with Wave Interactions & No & Yes \\
\hline Observations & 2,429 & 2,426 \\
\hline Pre-Treatment Mean for Treated Group & 12.0204 & \\
\hline \multicolumn{3}{|l|}{ Panel C: Married Women } \\
\hline Treated & $\begin{array}{c}0.3802 \\
(0.4278)\end{array}$ & $\begin{array}{l}-0.5735 \\
(0.5726)\end{array}$ \\
\hline Post-Reform & $\begin{array}{l}1.2284 * * \\
(0.5481)\end{array}$ & $\begin{array}{c}0.8705 \\
(1.1857)\end{array}$ \\
\hline Treated*Post-Reform & $\begin{array}{l}-1.3084 * * \\
(0.6441)\end{array}$ & $\begin{array}{l}-1.2933 * * \\
(0.6507)\end{array}$ \\
\hline Demographic Controls & No & Yes \\
\hline State Fixed Effects with Wave Interactions & No & Yes \\
\hline Observations & 2,802 & 2,800 \\
\hline Pre-Treatment Mean for Treated Group & 8.7644 & \\
\hline $\begin{array}{l}\text { Notes: Analyses are based on the National Survey of } \\
\text { and wave } 2 \text { (1992-1994). Standard errors, reported } \\
\text { clustering. The dependent variable is based on respo } \\
\text { controls include age, age-squared, race, marital statu } \\
\text { aged 13-18 in the household, and number of childrer } \\
\text { Missing dummy variables were created in cases whe }\end{array}$ & $\begin{array}{l}\text { Ind Households } \\
\text { es, are adjusted } \\
\text { 11-item CES-- } \\
\text { nal attainment, } \\
\text { he ages of } 0-18 \\
\text { phic informatic }\end{array}$ & $\begin{array}{l}1(1987-1988) \\
\text { dual-level } \\
\text { emographic } \\
\text { f children } \\
\text { sehold. } \\
\text { ssing. ***, **, }\end{array}$ \\
\hline
\end{tabular}


Table 4: The Impact of the EITC on Self-Reported Happiness

\begin{tabular}{|c|c|c|}
\hline Variable & (1) & (2) \\
\hline \multicolumn{3}{|l|}{ Panel A: All Women } \\
\hline \multirow[t]{2}{*}{ Treated } & $-0.1166^{*}$ & -0.0099 \\
\hline & $(0.0607)$ & $(0.0738)$ \\
\hline \multirow[t]{2}{*}{ Post-Reform } & $-0.1639 * *$ & -0.1223 \\
\hline & $(0.0740)$ & $(0.1572)$ \\
\hline \multirow[t]{2}{*}{ Treated*Post-Reform } & $0.2072 * *$ & 0.1075 \\
\hline & $(0.0893)$ & $(0.0906)$ \\
\hline Demographic Controls & No & Yes \\
\hline State Fixed Effects with Wave Interactions & No & Yes \\
\hline Observations & 4,760 & 4,755 \\
\hline Pre-Treatment Mean for Treated Group & 5.1918 & \\
\hline \multicolumn{3}{|l|}{ Panel B: Unmarried Women } \\
\hline \multirow[t]{2}{*}{ Treated } & -0.1424 & -0.0289 \\
\hline & $(0.0897)$ & $(0.1102)$ \\
\hline \multirow{2}{*}{ Post-Reform } & -0.1010 & -0.0618 \\
\hline & $(0.1067)$ & $(0.2498)$ \\
\hline \multirow[t]{2}{*}{ Treated*Post-Reform } & 0.1219 & 0.0056 \\
\hline & $(0.1344)$ & $(0.1394)$ \\
\hline Demographic Controls & No & Yes \\
\hline State Fixed Effects with Wave Interactions & No & Yes \\
\hline Observations & 2,204 & 2,201 \\
\hline Pre-Treatment Mean for Treated Group & 4.8636 & \\
\hline \multicolumn{3}{|l|}{ Panel C: Married Women } \\
\hline \multirow[t]{2}{*}{ Treated } & $-0.1429 *$ & -0.1214 \\
\hline & $(0.0781)$ & $(0.1016)$ \\
\hline \multirow[t]{2}{*}{ Post-Reform } & $-0.2195 * *$ & -0.1475 \\
\hline & $(0.1002)$ & $(0.2131)$ \\
\hline \multirow[t]{2}{*}{ Treated*Post-Reform } & $0.1967 *$ & $0.2113^{*}$ \\
\hline & $(0.1167)$ & $(0.1203)$ \\
\hline Demographic Controls & No & Yes \\
\hline State Fixed Effects with Wave Interactions & No & Yes \\
\hline Observations & 2,556 & 2,554 \\
\hline Pre-Treatment Mean for Treated Group & 5.4858 & \\
\hline \multicolumn{3}{|c|}{$\begin{array}{l}\text { Notes: Analyses are based on the National Survey of Families and Households for wave } 1 \text { (1987-1988) } \\
\text { and wave } 2 \text { (1992-1994). Standard errors, reported in parentheses, are adjusted for individual-level } \\
\text { clustering. The dependent variable is based on responses to the question: "First taking all things together, } \\
\text { how would you say things are these days?" The variable is ordinal where one indicates "very unhappy" } \\
\text { and seven indicates "very happy." Demographic controls include age, age-squared, race, marital status, } \\
\text { educational attainment, presence of children aged } 13-18 \text { in the household, and number of children } \\
\text { between the ages of } 0-18 \text { in the household. Missing dummy variables were created in cases where } \\
\text { demographic information was missing. ***,**, * indicate statistical significance at the } 0.01,0.05 \text {, and } \\
0.10 \text { levels, respectively. }\end{array}$} \\
\hline
\end{tabular}


Table 5: The Impact of the EITC on Reported Feelings of Self-Worth

\begin{tabular}{|c|c|c|}
\hline Variable & (1) & (2) \\
\hline \multicolumn{3}{|l|}{ Panel A: All Women } \\
\hline Treated & $\begin{array}{l}-0.0235 \\
(0.0188)\end{array}$ & $\begin{array}{l}0.0048 \\
(0.0246)\end{array}$ \\
\hline Post-Reform & $\begin{array}{l}-0.0500 * * \\
(0.0199)\end{array}$ & $\begin{array}{l}-0.0146 \\
(0.0517)\end{array}$ \\
\hline Treated*Post-Reform & $\begin{array}{c}0.0395 \\
(0.0245)\end{array}$ & $\begin{array}{c}0.0449 * \\
(0.0252)\end{array}$ \\
\hline Demographic Controls & No & Yes \\
\hline State Fixed Effects with Wave Interactions & No & Yes \\
\hline Observations & 3,490 & 3,485 \\
\hline Pre-Treatment Mean for Treated Group & 0.8675 & \\
\hline \multicolumn{3}{|l|}{ Panel B: Unmarried Women } \\
\hline Treated & $\begin{array}{l}-0.0245 \\
(0.0621)\end{array}$ & $\begin{array}{c}0.0511 \\
(0.0681)\end{array}$ \\
\hline Post-Reform & $\begin{array}{l}-0.0109 \\
(0.0494)\end{array}$ & $\begin{array}{c}0.1383 \\
(0.1629)\end{array}$ \\
\hline Treated*Post-Reform & $\begin{array}{c}0.0149 \\
(0.0669)\end{array}$ & $\begin{array}{l}-0.0108 \\
(0.0696)\end{array}$ \\
\hline Demographic Controls & No & Yes \\
\hline State Fixed Effects with Wave Interactions & No & Yes \\
\hline Observations & 1,061 & 1,058 \\
\hline Pre-Treatment Mean for Treated Group & 0.8193 & \\
\hline \multicolumn{3}{|l|}{ Panel C: Married Women } \\
\hline Treated & $\begin{array}{l}-0.0273 \\
(0.0195)\end{array}$ & $\begin{array}{c}0.0006 \\
(0.0270)\end{array}$ \\
\hline Post-Reform & $\begin{array}{l}-0.0496 * * \\
(0.0246)\end{array}$ & $\begin{array}{l}-0.0465 \\
(0.0596)\end{array}$ \\
\hline Treated*Post-Reform & $\begin{array}{c}0.0556^{*} \\
(0.0293)\end{array}$ & $\begin{array}{l}0.0645 * * \\
(0.0301)\end{array}$ \\
\hline Demographic Controls & No & Yes \\
\hline State Fixed Effects with Wave Interactions & No & Yes \\
\hline Observations & 2,429 & 2,427 \\
\hline Pre-Treatment Mean for Treated Group & 0.8721 & \\
\hline \multicolumn{3}{|c|}{$\begin{array}{l}\text { Notes: Analyses are based on the National Survey of Families and Households for wave } 1 \text { (1987-1988) } \\
\text { and wave } 2 \text { (1992-1994). Standard errors, reported in parentheses, are adjusted for individual-level } \\
\text { clustering. The dependent variable is based on agreement to the statement: "I feel that I'm a person of } \\
\text { worth, at least on an equal place with others." The variable is binary and equal to unity if a given } \\
\text { respondent reported any agreement with the statement. Demographic controls include age, age-squared, } \\
\text { race, marital status, educational attainment, presence of children aged } 13-18 \text { in the household, and number } \\
\text { of children between the ages of } 0-18 \text { in the household. Missing dummy variables were created in cases } \\
\text { where demographic information was missing. ***, **, indicate statistical significance at the } 0.01,0.05 \text {, } \\
\text { and } 0.10 \text { levels, respectively. }\end{array}$} \\
\hline
\end{tabular}


Table 6: The Impact of the EITC on Reported Feelings of Satisfaction with Self

\begin{tabular}{lll}
\hline Variable & $\mathbf{( 1 )}$ & $\mathbf{( 2 )}$ \\
\hline $\begin{array}{l}\text { Panel A: All Women } \\
\text { Treated }\end{array}$ & -0.0382 & -0.0081 \\
$\quad$ Post-Reform & $(0.0235)$ & $(0.0298)$ \\
$\quad$ Treated*Post-Reform & $-0.0875^{* * *}$ & -0.0697 \\
$\quad$ & $(0.0249)$ & $(0.0613)$ \\
$\quad$ & 0.0386 & 0.0331 \\
Demographic Controls & $(0.0305)$ & $(0.0314)$ \\
State Fixed Effects with Wave Interactions & & \\
Observations & No & Yes \\
Pre-Treatment Mean for Treated Group & No & Yes \\
& 3,498 & 3,493 \\
\end{tabular}

\section{Panel B: Unmarried Women}

$\begin{array}{lll}\text { Treated } & -0.0794 & -0.0985 \\ & (0.0753) & (0.0858) \\ \text { Post-Reform } & -0.0368 & -0.1327 \\ \text { Treated*Post-Reform } & (0.0602) & (0.1849) \\ & 0.0386 & -0.0566 \\ & (0.0818) & (0.0911)\end{array}$

Demographic Controls

$\begin{array}{ll}\text { No } & \text { Yes } \\ \text { No } & \text { Yes } \\ 1,070 & 1,067 \\ 0.6667 & \end{array}$

State Fixed Effects with Wave Interactions

0.6667

Pre-Treatment Mean for Treated Group

\begin{tabular}{|c|c|c|}
\hline \multicolumn{3}{|l|}{ Panel C: Married Women } \\
\hline \multirow[t]{2}{*}{ Treated } & -0.0392 & -0.0028 \\
\hline & $(0.0246)$ & $(0.0328)$ \\
\hline \multirow[t]{2}{*}{ Post-Reform } & $-0.0836 * * *$ & -0.0707 \\
\hline & $(0.0306)$ & $(0.0731)$ \\
\hline \multirow[t]{2}{*}{ Treated*Post-Reform } & 0.0594 & 0.0468 \\
\hline & $(0.0365)$ & $(0.0374)$ \\
\hline Demographic Controls & No & Yes \\
\hline State Fixed Effects with Wave Interactions & No & Yes \\
\hline Observations & 2,428 & 2,426 \\
\hline Pre-Treatment Mean for Treated Group & 0.7826 & \\
\hline \multicolumn{3}{|c|}{$\begin{array}{l}\text { Notes: Analyses are based on the National Survey of Families and Households for wave } 1 \text { (1987-1988) } \\
\text { and wave } 2 \text { (1992-1994). Standard errors, reported in parentheses, are adjusted for individual-level } \\
\text { clustering. The dependent variable is based on agreement to the statement: "On the whole I am satisfied } \\
\text { with myself." The variable is binary and equal to unity if a given respondent reported any agreement with } \\
\text { the statement. Demographic controls include age, age-squared, race, marital status, educational } \\
\text { attainment, presence of children aged } 13-18 \text { in the household, and number of children between the ages } \\
\text { of } 0-18 \text { in the household. Missing dummy variables were created in cases where demographic } \\
\text { information was missing. ***,**, * indicate statistical significance at the } 0.01,0.05 \text {, and } 0.10 \text { levels, } \\
\text { respectively. }\end{array}$} \\
\hline
\end{tabular}


Table 7: The Impact of the EITC on Reported Feelings of Self-Efficacy

\begin{tabular}{ccc}
\hline Variable & $\mathbf{( 1 )}$ & $\mathbf{( 2 )}$ \\
\hline Panel A: All Women & & \\
Treated & 0.0334 & 0.0117 \\
& $(0.0228)$ & $(0.0275)$ \\
Post-Reform & $-0.0501 * *$ & 0.0285 \\
Treated*Post-Reform & $(0.0247)$ & $(0.0573)$ \\
& 0.0353 & 0.0261 \\
& $(0.0293)$ & $(0.0298)$ \\
Demographic Controls & & Yes \\
State Fixed Effects with Wave Interactions & No & Yes \\
Observations & No & 3,479 \\
Pre-Treatment Mean for Treated Group & 3,484 &
\end{tabular}

\section{Panel B: Unmarried Women}

Treated

$0.0738 \quad 0.0950$

$(0.0633)$

$(0.0629)$

Post-Reform

$-0.0069$

0.0637

Treated*Post-Reform

(0.0557)

$(0.1425)$

$-0.0371$

$-0.0898$

$(0.0685)$

$(0.0652)$

Demographic Controls

$\begin{array}{ll}\text { No } & \text { Yes } \\ \text { No } & \text { Yes } \\ 1,062 & 1,059 \\ 0.8675 & \end{array}$

State Fixed Effects with Wave Interactions

0.8675

Pre-Treatment Mean for Treated Group

\begin{tabular}{|c|c|c|}
\hline \multicolumn{3}{|l|}{ Panel C: Married Women } \\
\hline \multirow[t]{2}{*}{ Treated } & 0.0287 & 0.0033 \\
\hline & $(0.0245)$ & $(0.0315)$ \\
\hline \multirow[t]{2}{*}{ Post-Reform } & $-0.0882 * * *$ & 0.0253 \\
\hline & $(0.0315)$ & $(0.0683)$ \\
\hline \multirow[t]{2}{*}{ Treated*Post-Reform } & $0.0753 * *$ & $0.0732 * *$ \\
\hline & $(0.0364)$ & $(0.0369)$ \\
\hline Demographic Controls & No & Yes \\
\hline State Fixed Effects with Wave Interactions & No & Yes \\
\hline Observations & 2,422 & 2,420 \\
\hline Pre-Treatment Mean for Treated Group & 0.8337 & \\
\hline \multicolumn{3}{|c|}{$\begin{array}{l}\text { Notes: Analyses are based on the National Survey of Families and Households for wave } 1 \text { (1987-1988) } \\
\text { and wave } 2 \text { (1992-1994). Standard errors, reported in parentheses, are adjusted for individual-level } \\
\text { clustering. The dependent variable is based on agreement to the statement: "I am able to do things as well } \\
\text { as other people." The variable is binary and equal to unity if a given respondent reported any agreement } \\
\text { with the statement. Demographic controls include age, age-squared, race, marital status, educational } \\
\text { attainment, presence of children aged } 13-18 \text { in the household, and number of children between the ages } \\
\text { of } 0-18 \text { in the household. Missing dummy variables were created in cases where demographic } \\
\text { information was missing. ***,**, * indicate statistical significance at the } 0.01,0.05 \text {, and } 0.10 \text { levels, } \\
\text { respectively. }\end{array}$} \\
\hline
\end{tabular}


Table 8: Robustness Checks

\begin{tabular}{|c|c|c|c|c|c|}
\hline Outcome & (1) & (2) & (3) & (4) & (5) \\
\hline \multicolumn{6}{|l|}{ Panel A: Unmarried Women } \\
\hline \multirow{2}{*}{ Employment } & $0.0788 * *$ & 0.0672 & $0.0894 * *$ & $0.0873 * *$ & 0.0168 \\
\hline & $(0.0385)$ & $(0.0411)$ & $(0.0398)$ & $(0.0389)$ & $(0.0240)$ \\
\hline \multirow[t]{2}{*}{ CES-D Scale } & -0.5757 & -0.3586 & -0.3966 & -0.5378 & -0.0314 \\
\hline & $(0.7710)$ & $(0.8317)$ & $(0.7921)$ & $(0.7729)$ & $(0.4667)$ \\
\hline \multirow[t]{2}{*}{ Happiness } & 0.0160 & 0.0326 & -0.0477 & -0.0128 & 0.0423 \\
\hline & $(0.1409)$ & $(0.1503)$ & $(0.1434)$ & $(0.1414)$ & $(0.0861)$ \\
\hline \multirow[t]{2}{*}{ Self-Worth } & -0.0124 & 0.0079 & -0.0095 & -0.0071 & -0.0207 \\
\hline & $(0.0688)$ & $(0.0727)$ & $(0.0796)$ & $(0.0721)$ & $(0.0517)$ \\
\hline \multirow[t]{2}{*}{ Satisfaction with Self } & 0.0491 & 0.0844 & 0.0339 & 0.0551 & 0.0182 \\
\hline & $(0.0903)$ & $(0.0935)$ & $(0.1030)$ & $(0.0944)$ & $(0.0678)$ \\
\hline \multirow[t]{2}{*}{ Self-Efficacy } & -0.0905 & -0.0766 & -0.0916 & -0.0844 & -0.0272 \\
\hline & $(0.0654)$ & $(0.0674)$ & $(0.0737)$ & $(0.0673)$ & $(0.0489)$ \\
\hline Demographic Controls & Yes & Yes & Yes & Yes & Yes \\
\hline State Fixed Effects (Wave Interactions) & Yes & Yes & No & Yes & Yes \\
\hline Month of Interview Controls & Yes & No & No & No & No \\
\hline Omit Observations from 1994 & No & Yes & No & No & No \\
\hline State Fixed Effects (Year Interactions) & No & No & Yes & No & No \\
\hline State-Specific Linear Time Trends & No & No & No & Yes & No \\
\hline Remove Age and Education Restrictions & No & No & No & No & Yes \\
\hline \multicolumn{6}{|l|}{ Panel B: Married Women } \\
\hline \multirow[t]{2}{*}{ Employment } & 0.0475 & 0.0584 & 0.0469 & 0.0431 & 0.0270 \\
\hline & $(0.0375)$ & $(0.0392)$ & $(0.0383)$ & $(0.0375)$ & $(0.0225)$ \\
\hline \multirow[t]{2}{*}{ CES-D Scale } & $-1.3191 * *$ & $-1.6354 * *$ & $-1.447 * *$ & $-1.3832 * *$ & -0.4454 \\
\hline & $(0.6542)$ & $(0.6891)$ & $(0.6684)$ & $(0.6553)$ & $(0.3672)$ \\
\hline \multirow[t]{2}{*}{ Happiness } & $0.2133^{*}$ & $0.2116^{*}$ & $0.2345^{*}$ & $0.2279 *$ & 0.0355 \\
\hline & $(0.1208)$ & $(0.1255)$ & $(0.1245)$ & $(0.1222)$ & $(0.0708)$ \\
\hline \multirow[t]{2}{*}{ Self-Worth } & $0.0651 * *$ & $0.0734 * *$ & $0.0661 * *$ & $0.0640 * *$ & 0.0230 \\
\hline & $(0.0302)$ & $(0.0315)$ & $(0.0308)$ & $(0.0303)$ & $(0.0177)$ \\
\hline \multirow[t]{2}{*}{ Satisfaction with Self } & 0.0485 & 0.0585 & 0.0456 & 0.0532 & $0.0432 *$ \\
\hline & $(0.0376)$ & $(0.0395)$ & $(0.0382)$ & $(0.0377)$ & $(0.0229)$ \\
\hline \multirow[t]{2}{*}{ Self-Efficacy } & $0.0767 * *$ & $0.0811 * *$ & $0.0704 *$ & $0.0732 * *$ & $0.0536 * *$ \\
\hline & $(0.0370)$ & $(0.0387)$ & $(0.0374)$ & $(0.0370)$ & $(0.0220)$ \\
\hline Demographic Controls & Yes & Yes & Yes & Yes & Yes \\
\hline State Fixed Effects (Wave Interactions) & Yes & Yes & No & Yes & Yes \\
\hline Month of Interview Controls & Yes & No & No & No & No \\
\hline Omit Observations from 1994 & No & Yes & No & No & No \\
\hline State Fixed Effects (Year Interactions) & No & No & Yes & No & No \\
\hline State-Specific Linear Time Trends & No & No & No & Yes & No \\
\hline Remove Age and Education Restrictions & No & No & No & No & Yes \\
\hline
\end{tabular}


Table 9: Test for Pre-OBRA90 Differences in Happiness Trends, General Social Survey, 1972-1990 Survey Question: "Taken all together, how would you say things are these dayswould you say that you are very happy, pretty happy, or not too happy?"

\begin{tabular}{lcccc}
\hline & Observations & With Kids & Without Kids & Difference \\
Sample & $(\mathbf{1})$ & $\mathbf{( 2 )}$ & $\mathbf{( 3 )}$ & $\mathbf{( 4 )}$ \\
\hline Unmarried Women & 2,556 & -0.4273 & -0.4474 & 0.0201 \\
& & $(0.6974)$ & $(0.7718)$ & $(0.7674)$ \\
Married Women & & & 0.4433 & -0.5256 \\
& 4,611 & -0.0823 & $(0.995)$ \\
\hline Notes: Each cell in columns (2) and (3) reports the coefficient (and standard error, in parentheses) on a linear time trend from
\end{tabular}

Notes: Each cell in columns (2) and (3) reports the coefficient (and standard error, in parentheses) on a linear time trend from
an ordered probit happiness regression. The top row is based on an analysis of unmarried women (with and without children), and the second row is based on an analysis of married women (with and without children). The figures in column (4) report the difference in the linear time trend coefficients between women with and without children, testing the null hypothesis of no difference in the trend coefficients. Both models include controls for race, age, educational attainment, employment status, household income, presence and number of children in the household, and region of residence. ***, **, * indicate statistical significance at the $0.01,0.05$, and 0.10 levels, respectively. 
Appendix Table 1: The Impact of the EITC on the Items in the CES-D Scale

\begin{tabular}{|c|c|c|c|}
\hline & $\begin{array}{l}\text { All Women } \\
\text { (1) }\end{array}$ & $\begin{array}{l}\text { Unmarried Women } \\
\text { (2) }\end{array}$ & $\begin{array}{l}\text { Married Women } \\
\text { (3) }\end{array}$ \\
\hline Depressed & $\begin{array}{l}0.1069 * * * \\
(0.0279)\end{array}$ & $\begin{array}{l}0.1074 * * * \\
(0.0397)\end{array}$ & $\begin{array}{l}0.1030^{* *} \\
(0.0405)\end{array}$ \\
\hline Lonely & $\begin{array}{l}0.0929 * * * \\
(0.0287)\end{array}$ & $\begin{array}{c}0.0268 \\
(0.0426)\end{array}$ & $\begin{array}{l}0.1496 * * * \\
(0.0404)\end{array}$ \\
\hline Sad & $\begin{array}{l}0.0576 * * \\
(0.0284)\end{array}$ & $\begin{array}{c}0.0255 \\
(0.0416)\end{array}$ & $\begin{array}{l}0.0804 * * \\
(0.0406)\end{array}$ \\
\hline Bothered & $\begin{array}{l}0.0754 * * * \\
(0.0276)\end{array}$ & $\begin{array}{r}0.0774 * \\
(0.0410)\end{array}$ & $\begin{array}{r}0.0745 * \\
(0.0389)\end{array}$ \\
\hline Appetite & $\begin{array}{l}0.0667 * * \\
(0.0290)\end{array}$ & $\begin{array}{r}0.0740 * \\
(0.0423)\end{array}$ & $\begin{array}{c}0.0651 \\
(0.0419)\end{array}$ \\
\hline Blue & $\begin{array}{r}0.0527^{*} \\
(0.0288)\end{array}$ & $\begin{array}{c}0.0499 \\
(0.0433)\end{array}$ & $\begin{array}{l}(0.0367 \\
(0.0405)\end{array}$ \\
\hline Effort & $\begin{array}{l}0.0765^{* * *} \\
(0.0290)\end{array}$ & $\begin{array}{c}0.0679 \\
(0.0433)\end{array}$ & $\begin{array}{l}0.0736^{* *} \\
(0.0405)\end{array}$ \\
\hline Fearful & $\begin{array}{l}0.0757 * * * \\
(0.0278)\end{array}$ & $\begin{array}{r}0.0812^{*} \\
(0.0427)\end{array}$ & $\begin{array}{c}0.0479 \\
(0.0386)\end{array}$ \\
\hline Sleep & $\begin{array}{c}0.0457 \\
(0.0281)\end{array}$ & $\begin{array}{c}0.0370 \\
(0.0416)\end{array}$ & $\begin{array}{c}0.0572 \\
(0.0401)\end{array}$ \\
\hline Talks Less & $\begin{array}{c}0.0421 \\
(0.0290)\end{array}$ & $\begin{array}{l}-0.0106 \\
(0.0434)\end{array}$ & $\begin{array}{l}0.0873 * * \\
(0.0407)\end{array}$ \\
\hline Get Going & $\begin{array}{l}0.0202 \\
(0.0285)\end{array}$ & $\begin{array}{l}0.0215 \\
(0.0425)\end{array}$ & $\begin{array}{l}0.0142 \\
(0.0404)\end{array}$ \\
\hline
\end{tabular}

Notes: Analyses are based on the National Survey of Families and Households for wave 1 (1987-1988) and wave 2 (1992-1994). Standard errors, reported in parentheses, are adjusted for individual-level clustering. Each depression scale individual item is binary and equal to one if indicated zero days when they experienced the item during the week and equal to zero if they reported any days when they experienced the item. Demographic controls include age, agesquared, race, marital status, educational attainment, presence of children aged 13-18 in the household, and number of children between the ages of 0-18 in the household. Missing dummy variables were created in cases where demographic information was missing, except for age and information on children in the household. ***, **, * indicate statistical significance at the $0.01,0.05$, and 0.10 levels, respectively. 